https://cssr.uitm.edu.my/2018/

5th International Conference on Science and Social Research

Le Meridien Kota Kinabalu Hotel, 5 - 6 December 2018

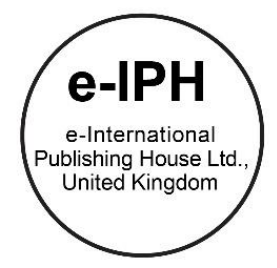

\title{
Protection of Child Offenders at the Pre-Trial Process in Malaysia: Are we doing enough?
}

\author{
Nadzriah Ahmad', Abdul Ghafur Hamid², Saodah Wok ${ }^{3}$ \\ ${ }^{1}$ Faculty of Law, Universiti Teknologi MARA, 40450, Shah Alam, Selangor, Malaysia \\ ${ }^{2}$ Ahmad Ibrahim Kulliyyah of Laws, International Islamic University Malaysia, Gombak, 50728, Malaysia \\ ${ }^{3}$ Kulliyyah of Islamic Revealed Knowledge and Human Sciences, International Islamic University Malaysia, Gombak, 50728, Malaysia \\ nadzriahahmad@gmail.com, ghafur@iium.edu.my,wsaodah@iium.edu.my \\ Tel: 014-6631466
}

\begin{abstract}
The adverse effects of the pre-trial process on child offenders are damaging, particularly on their mental, emotional and physical developments. This study adopted the qualitative design, and the results indicate that the majority of the child offenders affirmed that they were subjected to some forms of ill-treatment during the pre-trial process, particularly during the investigation stage, where they are subjected to questioning. Thus, the results can facilitate the policymakers in strengthening and developing the current laws and policies and to introduce diversion programmes as an alternative to the juvenile justice system in Malaysia.
\end{abstract}

Keywords: pre-trial process; questioning, juveniles; ill-treatment.

eISSN: 2398-4287@ 2020. The Authors. Published for AMER ABRA cE-Bsby e-International Publishing House, Ltd., UK. This is an open access article under the CC BYNC-ND license (http://creativecommons.org/licenses/by-nc-nd/4.0/). Peer-review under responsibility of AMER (Association of Malaysian Environment-Behaviour Researchers), ABRA (Association of Behavioural Researchers on Asians) and CE-Bs (Centre for Environment-Behaviour Studies), Faculty of Architecture, Planning \& Surveying, Universiti Teknologi MARA, Malaysia.

DOI: https://doi.org/10.21834/ebpj.v5iSI3.2571

\subsection{Introduction}

In Malaysia, by virtue of Section 2 (a) of the Child Act 2001 (hereinafter referred to as the 2001 Act) a child is defined as a person who is below the age of eighteen (18) years old. Further, Section 2 (b) of the 2001 Act provides that in relation to criminal proceedings, a child is a person who has attained the age of criminal responsibility according to Section 82 of the Penal Code. Child offenders are often vulnerable at the pre-trial process because, for the majority of them, it is their first time coming into contact with the police officers in the juvenile justice system in Malaysia. The laws governing the juvenile justice system in Malaysia are encapsulated in Part $X$ of the 2001 Act, which outlines the procedures and trial governing the juvenile justice system in Malaysia. However, in the absence of specific provisions governing the juvenile justice system in the 2001 Act, reference can be made to the provisions in the Criminal Procedure Code (hereinafter referred to as the CPC). In addition to the domestic laws, Malaysia has also acceded to the Convention on the Rights of the Child 1989 (hereinafter referred to as the CRC 1989) in 1995 which imposed obligations on Malaysia to carry out the provisions in the CRC 1989, by virtue of Article 4 of the CRC. Articles 37 and 40 of the CRC 1989 outlines the rights of the child offenders in the juvenile justice system, and States Parties need to meet at least the minimum guarantees and safeguards in the CRC 1989 to ensure those child offenders are protected at all stages in the juvenile justice system.

eISSN: 2398-4287○ 2020. The Authors. Published for AMER ABRA cE-Bsby e-International Publishing House, Ltd., UK. This is an open access article under the CC BYNC-ND license (http://creativecommons.org/licenses/by-nc-nd/4.0). Peer-review under responsibility of AMER (Association of Malaysian Environment-Behaviour Researchers), ABRA (Association of Behavioural Researchers on Asians) and cE-Bs (Centre for Environment-Behaviour Studies), Faculty of Architecture, Planning \& Surveying, Universiti Teknologi MARA, Malaysia. DOI: https://doi.org/10.21834/ebpj.v5iSI3.2571 
Additionally, the Committee on the CRC in its General Comment No. 24 (2019), entitled, Children's Rights in the Child Justice System (hereinafter referred to as General Comment No. 24) specifically highlighted that one of the objectives of General Comment No. 24 is to ensure that States Parties take into account the provisions in the CRC in ensuring that juvenile justice system is implemented holistically. Children's rights in the justice system are upheld. Many issues are surrounding the protection of child offenders in the pre-trial process in Malaysia. However, the objectives of this paper are to examine the adequacy of the existing legal framework particularly in protecting child offenders from ill-treatment at the pre-trial process particularly where they are subjected to questioning and whether the laws are in line with the provisions in the CRC 1989 and the international legal framework.

\subsection{The Legal Framework}

In Malaysia, the police officers are under an obligation to ensure that arrested persons are informed of their rights by virtue of Section $28 \mathrm{~A}$ of the CPC, especially before they conduct any forms of questioning or recording of any statement from the arrested persons. Section 28A is incorporated in the CPC to ensure that the rights of detained persons are safeguarded upon arrest. Section $28 \mathrm{~A}(2)$ of the CPC outlines the following measures that need to be compiled by the police officers. Firstly, the police officers shall, before conducting any form of questioning or recording of any statement on the arrested persons, informed the person that he has the following rights: may communicate or attempt to notify with a relative or friend to tell about his whereabouts, and may communicate or try to communicate and consult with his preferred lawyer.

In addition to the provisions in the CPC above, the new Section 83A (2) of the 2001 Act is incorporated expressly for child offenders. It provides guidelines to the police officers in handling child offenders. This section provides that following the arrest of the child, he shall be informed of the grounds of detention and before the commencement of any form of questioning or recording, the police officer must first communicate with the parent, guardian or relative of the child and contacted the probation officer to inform him about the child's whereabouts, the grounds of arrest and the child's right to have access to a legal practitioner of his choice. Police officers will then proceed to conduct questioning under Section 112 of the CPC to assist the police officers with the investigation Section 112 CPC vested the powers the police officers to conduct an interview and record a statement from witnesses who are acquainted with the facts and circumstances of the case (Srimurugan, 2016). The purpose of recording statement of child offenders under Section 112 CPC is to facilitate the police officers in their investigation, and this statement forms part of the evidence that the Prosecution can adduce during the trial (Mohamed Yusof bin Haji Ahmad v PP (1983) 2 MLJ 167).

In addition to the domestic laws, there are also provisions in the CRC 1989 that seek to protect the child offenders. For instance, Article 37 (a) of the CRC urge States Parties to prohibit any form of torture or other cruel, inhuman or degrading treatment against child offenders. The Committee on the CRC in its General Comment No. 13 (2011), entitled, The Right of the Child to Freedom From All Forms of Violence (hereinafter referred to as General Comment No. 13), recognises that in the juvenile justice system, child offenders often become victims of police and law police officers, the staff of residential and other institutions and any other persons who have power over them (General Comment No. 13 at para 26). States must also ensure that in ensuring the best interest of the child offenders, their safety must be taken into account at all times by protecting them from all forms of physical or mental violence, injury or abuse, sexual harassment, peer pressure, bullying and degrading treatment (General Comment No. 13 (2011), entitled, The Right Of The Child To Have His Or Her Best Interests Taken As A Primary Consideration (Art. 3, Para. 1) at para 73).

Additionally, the Committee on the CRC in its General Comment No. 24 (2019), entitled, Children's Rights in the Child Justice System (hereinafter referred to as General Comment No. 24) specifically prohibited child offenders from being subjected to illtreatment at the pre-trial process. The acts of torture or other cruel, inhuman or degrading treatment, particularly inflicted on child offenders when extracting confession and to extra-judicially punish them for unlawful or unwanted behaviours or to coerce them to engage in activities against their will violate Article 37 (a) of the CRC (General Comment No. 13 at para 26). In addition, these acts also infringe the provision in Article 19 of the CRC and the general principles of the CRC highlighted above specified in Articles 2, 36 and 12 of the CRC (General Comment No. 13 at para 60-63). Furthermore, Article 37 (a) of the CRC is also consistent with Rule 31 of the Standard Minimum Rules for the Treatment of Prisoners (1955) that prohibits the imposition of corporal punishment, placing prisoners in dark cells and other forms of cruel, inhuman or degrading punishment on prisoners (Standard Minimum Rules for the Treatment of Prisoners).

\subsection{Methodology}

The findings discussed in the article are derived from the qualitative research design which aims primarily in obtaining in-depth views and opinions from respondents who are part of the juvenile justice system in Malaysia (Creswell, 2007, 2009). The primary data of this research is obtained from semi-structured interviews conducted with the respondents ( 25 respondents/stakeholders and open-ended survey questions with 432 child offenders) to obtain feedback from the interview protocols prepared (Anwarul Yaqin, 2007). Besides, document analysis is undertaken to analyse the feedback provided by the child offenders who were serving sentences in the institutions to identify the adverse effects of the pre-trial process on child offenders, particularly at the pre-trial process when they came into contact with the juvenile justice system. 


\subsection{Findings}

Some of the key findings of from the qualitative study highlighted that child offender may feel tormented when they are subjected to oppressive tactics used by police officers as a tool to obtain information from them during an investigation, at the pre-trial process, resulting in them giving involuntary information.

\subsection{Discussions}

The majority of child offenders come into contact with the police officers for the first time when they committed a crime and become part of the criminal justice system. Hence, it is of utmost importance for the police officers to treat and respect their legal status as a child or juvenile offender and taking into account the circumstances of the case, avoid causing harm on child offenders in the course of the investigation (Beijing Rules, 1990). The findings that the child offenders are traumatised during the pre-trial process seem to lend support to the opinion of scholars who opined that often, during the pre-trial process, the child offenders were susceptible to abuse and maltreatment (Fara Nini Dusuki, 2009). Thus, drawing from these findings, an inference can be made that subjecting the child offenders to mistreatments are not in concert with Article 37 (a) of the CRC 1989 which provides that a child should not be subjected to acts of torture, or other cruel, inhuman or degrading treatment or punishment. The importance of addressing the child offenders' needs and to treat them differently is enshrined in Article 37 (c) of the CRC which provides that every child deprived of liberty shall be treated with humanity and respect for the inherent dignity of the human person and shall take into account the child's needs according to his or her age. Additionally, the feelings of intimidation suffered by the child offenders at the pre-trial process do not conform with the treatment that must be accorded to them, consistent with their sense of worth and dignity, as prescribed in Article 40 (1) of the CRC.

The findings also indicate that while being detained, ill-treatment was used against child offenders as a tool to enable the police officers to obtain information from them. Hence, the information given by child offenders would be involuntary due to the stressful circumstances they were facing. These findings seem to be consistent with the opinion of the scholars and are substantiated by various studies which highlighted those child offenders provided involuntarily admission due to feeling of intimidation they have towards the police officers (Nadzriah Ahmad \& Habibah Kiprawi, 2012), use of force employed by the police officers against the child offenders (SUHAKAM, 2005; Nadzriah Ahmad \& Habibah Kiprawi, 2012) and the use of improper interrogation tactics and pressure to coerce child offenders to make confession for the alleged crime committed or for crimes they did not commit (MWFCD \& UNICEF, 2013, Mustaffa, et al, 2018). Lapp (2017) highlighted that based on studies conducted, police officers employed similar old school, relentless, psychologically manipulative interrogation techniques with child offenders, as they do with adult offenders. Child offenders need to be treated differently from adult offenders at all stages of the administration of juvenile justice system in order to afford them better protection (Havana Rules, 1990) Another study further highlighted that even though police officers are informed about child offenders' diminished developmental capacities and psychosocial maturity, they do not seem to apply this knowledge when conducting interrogation with child offenders (Lapp, 2017). Child offenders need to be protected from the techniques described above since they are uniquely vulnerable and they can be coerced into admitting their guilt or confess to crimes they did not commit in the first place (McMullen, 2005).

The findings in this study also do not seem to be in line with Article 40 (2) (b) (iv) of the CRC 1989 that prohibits any act of torture, cruel, inhuman or degrading treatment against child offenders in order to compel them to confess or acknowledge guilt. Additionally, the Committee on the CRC emphasised that any forms of coercion (which extends beyond physical force) used that lead a child to a confession or self-incriminatory is impermissible. Further, the Committee recognised that the risk of false confession is intensified when the following factors are present: (a) the child's age and development; (b) lack of understanding; (c) fear of unknown consequences; and (d) length and circumstances of the questioning (General Comment No. 24 at para 59). This newly incorporated provision seems to be in line with the recommendation made by the Committee on the CRC in its General Comment No. 24 (2019) that provides child offenders must have access to legal assistance and during questioning, they must be supported by a parent, legal guardian or other appropriate adults (General Comment No. 24 at para 60). The need to have the presence of parents, responsible adults or legal practitioner during the investigation is integral to ensure those child offenders are protected and the information they give is voluntary and not improperly obtained or manufactured (Alder, O'Connor, warner and White, 1992). However, to ensure those child offenders are not subjected to ill-treatment during the process of questioning, police officers must recognise that child offenders must be treated differently than the adult offenders and they must be fully trained in conducting the questioning session with the child offenders. Police officers must be well trained so that they can act in an informed and appropriate manner when dealing with child offenders (Beijing Rules, 1990). Furthermore, the Committee on the CRC highlighted that it is integral to have well-trained officers conducting the questioning to avoid child offenders from being coerced or providing unreliable confessions or testimonies and audiovisual techniques should be used where possible (General Comment No. 24 at para 60).

\subsection{Conclusions and Recommendations}

The adverse effects of the pre-trial process on child offenders can be damaging to the overall well-being of the child offenders, especially at the pre-trial process when the police officers investigate with them. These effects are recognised by both stakeholders and child offenders who participated in the study. Hence, the findings from this study highlighted the need to improve the existing legal framework, policies and standard operating procedures when conducting an investigation against child offenders to ensure they are 
provided with better legal protection at the pre-trial process, especially during questioning. A specific standard operating procedure needs to be in place in order to ensure those child offenders are protected during questioning and the statement provided by them is voluntary. Besides, investments in building human capital through sufficient training among the police officers who are dealing with child offenders, particularly at the investigation process in Malaysia is fundamental to ensure those child offenders received differential treatment from the adult offenders. These measures need to be implemented in order to ensure that the needs of the child offenders are met at every stage of the juvenile justice system in Malaysia and to meet the minimum requirements prescribed by the CRC 1989 and other international legal frameworks.

\section{Acknowledgements}

The authors gratefully acknowledge the help of the Ministry of Education of Malaysia in providing the Exploratory Research Grant Scheme (ERGS). The authors are also thankful to Associate Professor Dr. Zaiton Hamin, Faculty of Law, Universiti Teknologi MARA, Shah Alam, Selangor, for heading the research grant.

\section{References}

Alder, C. O'Connor, I, warner, K. and White, R. (1992). Perceptions of the Treatment of Juveniles in the Legal System: National Clearinghouse for Youth Studies, Department of Education, the University of Tasmania at Hobart.

Anwarul Yaqin. (2007). Legal Research and Writing. Malaysia: Lexis Nexis.

Convention on the Rights of the Child: Report of the Roundtable Discussion (2005). Kuala Lumpur: Human Rights Commission of Malaysia.

CRC/C/GC/14 Committee on the Convention on the Rights of the Child General Comment No. 14. (2013). The Right Of The Child To Have His Or Her Best Interests Taken As A Primary Consideration (Art. 3, Para. 1).

CRC/C/GC/13 Committee on the Convention on the Rights of the Child General Comment No. 13. (2011). The Right of the Child to Freedom From All Forms of Violence.

CRC/C/GC/24 Committee on the Convention on the Rights of the Child General Comment No. 24. (2019). Children's Rights in the Child Justice System.

Creswell, John, W. (2009). Research Design Qualitative, Quantitative and Mixed Methods Approach. USA: Sage Publications.

Creswell, John, W. (2007). Qualitative Inquiry \& Research Design: Choosing Among Five Approaches The Practice of Research in Criminology and Criminal Justice Research. USA: Sage Publications.

Fara Nini Dusuki. (2009). The UN Convention on CRC and the Administration of Juvenile Justice: An Examination of the Legal Framework In Malaysia. Asia Law Quarterly, 1(2), 123-140.

Lapp, K. (2017). Taking Back Juvenile Confessions. University of California (UCLA) Law Review, 64 (4) 902 - 967.

McMullen, P.M. (2005). Questioning the Questions: The Impermissibility of Police Deception in Interrogations of Juveniles. Northwestern University Law Review, 99(2), $971-1006$.

Ministry of Women, Family and Community Development \& UNICEF. (2013). The Malaysian Juvenile Justice System: A Study of Mechanisms for Handling Children in Conflict with the Law. Kuala Lumpur.

Nadzriah Ahmad. (2011). The Administration of Juvenile Justice System in Malaysia: Moving Towards Restorative Justice Process. Jurnal Intelek, 1(6), 1-6.

Nadzriah Ahmad \& Habibah Kiprawi. (2012). A Critical study of the Pre Trial Process in the Juvenile Justice System in Malaysia under the Child Act 2001. Kuala Lumpur: Research Management Institute (RMI), UiTM Shah Alam, Malaysia Law Reform Committee.

United Nations General Assembly Resolution A/RES/45/113 (1990). Rules for the Protection of Juveniles Deprived of Their Liberty (Havana Rules).

United Nations General Assembly Resolution A/RES/40/33 (1990). United Nations Standard Minimum Rules for the Administration of Juvenile Justice (The Beijing Rules).

Srimurugan Alagan. (2016). The Criminal Procedure Code: A Commentary. Malaysia: Sweet \& Maxwell. 